\title{
Altered Baroreceptor Function in Children With Systolic Hypertension After Coarctation Repair
}

\author{
ROBERT H. BEEKMAN, MD, BARRY P. KATZ, MPH, \\ CATHERINE MOOREHEAD-STEFFENS, BS, and ALBERT P. ROCCHINI, MD
}

\begin{abstract}
To determine whether altered baroreceptor function may contribute to systemic hypertension after coarctation of the aorta (C of A) repair, baroreceptor function was evaluated in 6 children with repaired C of A mild arm systolic hypertension. Data were compared with those from 7 normotensive control children with hemodynamically mild heart disease. Age at $C$ of $A$ repair averaged $9.9 \pm 3.1$ years (mean \pm standard deviation [SD]). Arm systolic pressure was $143.8 \pm 2.9 \mathrm{~mm} \mathrm{Hg}$ in the $C$ of $A$ repair group, compared with $118.3 \pm 9.9$ for control subjects (p $<0.001)$. At catheterization, steady-state sigmoidal baroreceptor function curves relating mean arterial pressure to R-R interval were derived by Increasing
\end{abstract}

and decreasing mean arterial pressure with small injections of phenylephrine and nitroprusside. Compared with control subjects, the baroreceptor function curves of children with repaired $C$ of $A(1)$ are reset about a higher baseline mean arterial pressure $(108.8 \pm 6.6$ versus $90.3 \pm 8.6 \mathrm{~mm} \mathrm{Hg}$, $p$ $<0.01)$, (2) have a decreased slope (7.9 \pm 3.7 versus $17.4 \pm 3.6 \mathrm{~ms} / \mathrm{mm} \mathrm{Hg}, p<0.001$ ), and (3) have a diminished $R-R$ interval range $(246.7 \pm 81.5$ versus $535.7 \pm 97.2 \mathrm{~ms}, p<0.001)$. Thus, in children with hypertension after $\mathbf{C}$ of $A$ repair, the baroreflex is reset to an elevated mean arterial pressure level and has a diminished sensitivity to changes in arterial pressure.
Arm hypertension, at rest or during dynamic exercise, occurs frequently after repair of coarctation of the aorta (C of A).$^{1-5}$ In some patients, hypertension is clearly related to a residual or recurrent $\mathrm{C}$ of $\mathrm{A} .{ }^{6} \mathrm{In}$ others, however, those with little or no residual resting $\mathrm{C}$ of $\mathrm{A}$ gradient, the cause of postoperative hypertension is less clear. The baroreflex is intimately involved in blood pressure regulation, but its function in patients with repaired $\mathrm{C}$ of $\mathrm{A}$ has not been evaluated. Nevertheless, studies in dogs with experimental $C$ of $A^{7,8}$ have documented baroreflex alterations similar to those described in adults with chronic essential hypertension. ${ }^{9-11}$ The purpose of this study is to evaluate baroreceptor function in children with repaired $\mathrm{C}$ of $\mathrm{A}$ who have mild arm hypertension.

From the Division of Pediatric Cardiology, Department of Pediatrics, C. S. Mott Children's Hospital, and the Department of Biostatistics, the University of Michigan, Ann Arbor, Michigan. This study was supported in part by National Institutes of Health Grant MO 1 RR00042-21, Clinical Research Center, University Hospitals, Ann Arbor, Michigan. Manuscript received January 10, 1983; revised manuscript received April 4, 1983, accepted April 5, 1983.

Address for reprints: Albert P. Rocchini, MD, Section of Pediatric Cardiology, C. S. Mott Children's Hospital, F1123, Box 66, Ann Arbor, Michigan 48109

\section{Methods}

Six children, 5 boys and 1 girl, with good surgical repair of $\mathrm{C}$ of $\mathrm{A}$ (resting peak systolic gradient of $<25 \mathrm{~mm} \mathrm{Hg}$ ) and mild resting arm systolic hypertension $(>140 \mathrm{~mm} \mathrm{Hg})$ served as subjects of this investigation. A group of 7 normotensive children with hemodynamically mild heart disease served as control subjects. Pertinent clinical and hemodynamic data are presented in Table I. The children with repaired $\mathrm{C}$ of $\mathrm{A}$ ranged in age from 13.8 to 19.0 years, averaging $16.8 \pm 2.0$ years (mean $\pm \mathrm{SD}$ ). The control children averaged $15.4 \pm 4$ years of age, which is not significantly different from that in the $\mathrm{C}$ of $\mathrm{A}$ repair group. The 6 children with repaired $\mathrm{C}$ of $\mathrm{A}$ had undergone repair of a discrete thoracic $\mathrm{C}$ of $\mathrm{A}$ at an average age of $9.9 \pm 3.1$ years (range 6.8 to 13.8). Before $\mathrm{C}$ of $\mathrm{A}$ repair, all children had resting arm hypertension (defined as systolic pressure at or above the 95th percentile for age and sex) averaging $146.8 \pm 16.2 \mathrm{~mm} \mathrm{Hg}$. C of A repair was performed by end-to-end anastomosis in 4 children (Patients 3 to 6) and by patch aortoplasty in 2 (Patients 1 and 2). Immediately after surgical repair, 5 children (Patients 1, 2, 3,5, and 6) had paradoxical hypertension requiring vigorous antihypertensive therapy for 2 to 3 days. The interval from repair to the present study averaged $6.9 \pm 3.7$ years. At the time of this study, no patient was receiving antihypertensive medication or digoxin. There were no associated hemodynamic lesions of significance. One patient (Patient 4) had also undergone repair of a ventricular septal defect with excellent 
TABLE I Pertinent Clinical Data in 6 Children With Repaired Coarctation and 7 Control Children

\begin{tabular}{|c|c|c|c|c|c|c|c|c|c|c|}
\hline \multirow[b]{4}{*}{ Patient } & \multirow[b]{4}{*}{ Diagnosis } & \multirow[b]{4}{*}{ Age (yr) } & \multirow{4}{*}{$\begin{array}{l}\text { Age at } \\
\text { C of A } \\
\text { Repair } \\
\text { (yr) }\end{array}$} & \multicolumn{4}{|c|}{ Resting Outpatient Data } & \multirow{2}{*}{\multicolumn{3}{|c|}{ Treadmill Exercise }} \\
\hline & & & & \multirow{3}{*}{$\begin{array}{c}\text { HR } \\
\text { (beats/min) }\end{array}$} & \multirow{2}{*}{\multicolumn{2}{|c|}{$\begin{array}{c}\text { Rt Arm BP } \\
\text { (mm Hg) }\end{array}$}} & \multirow{3}{*}{$\begin{array}{l}\text { Rt Arm- } \\
\text { Rt Leg Syst } \\
\text { Gradient } \\
(\mathrm{mm} \mathrm{Hg})\end{array}$} & & & \\
\hline & & & & & & & & \multirow{2}{*}{$\begin{array}{c}\text { HR } \\
\text { Peak Ex } \\
\text { (beats/min) }\end{array}$} & \multirow{2}{*}{$\begin{array}{l}\text { Rt Arm Systolic } \\
\text { Pressure (mm Hg) } \\
\text { Post Ex }\end{array}$} & \multirow{2}{*}{$\begin{array}{c}\text { C of A Gradient } \\
\text { (mm Hg) } \\
\text { Post Ex }\end{array}$} \\
\hline & & & & & Syst & Dias & & & & \\
\hline \multicolumn{11}{|c|}{ Coarctation Repair } \\
\hline 1 & $\begin{array}{l}\text { Patch } \\
\text { aorto- } \\
\text { plasty }\end{array}$ & 13.8 & 12.9 & 93 & 142 & 82 & 8 & 184 & 206 & 32 \\
\hline 2 & $\begin{array}{l}\text { Patch } \\
\text { aorto- } \\
\text { plasty }\end{array}$ & 18.2 & 13.8 & 76 & 145 & 70 & 6 & 202 & 210 & 86 \\
\hline 3 & $\begin{array}{l}\text { End-to-end } \\
\text { anasto- } \\
\text { mosis }\end{array}$ & 14.4 & 6.8 & 81 & 141 & 60 & 7 & 198 & 240 & 90 \\
\hline 4 & $\begin{array}{l}\text { End-to-end } \\
\text { anasto- } \\
\text { mosis }\end{array}$ & 19.0 & 11.9 & 85 & 146 & 80 & 0 & 182 & 220 & 40 \\
\hline 5 & $\begin{array}{l}\text { End-to-end } \\
\text { anasto- } \\
\text { mosis }\end{array}$ & 17.1 & 6.8 & 76 & 141 & 70 & 28 & 188 & 230 & 120 \\
\hline 6 & $\begin{array}{l}\text { End-to-end } \\
\text { anasto- } \\
\text { mosis }\end{array}$ & 13.3 & 7.2 & 71 & 148 & 85 & 2 & 189 & 234 & 83 \\
\hline $\begin{array}{l}\text { Mean } \\
\pm S D \\
\text { p value* }\end{array}$ & & $\begin{array}{l}16.8 \\
\pm 2.0 \\
\text { NS }\end{array}$ & $\begin{array}{r}9.9 \\
\pm 3.1 \\
\ldots\end{array}$ & $\begin{array}{c}80.3 \\
\pm 7.8 \\
\text { NS }\end{array}$ & $\begin{array}{l}143.8 \\
\pm 2.9 \\
<0.04\end{array}$ & $\begin{array}{c}74.5 \\
\pm 9.4 \\
N S\end{array}$ & $\begin{array}{c}7.8 \\
\pm 10.6 \\
<0.05\end{array}$ & $\begin{array}{l}190.5 \\
\pm 7.9 \\
\text { NS }\end{array}$ & $\begin{array}{l}223.3 \\
\pm 13.6 \\
<0.001\end{array}$ & $\begin{array}{r}75.2 \\
\pm 33.2 \\
\ldots\end{array}$ \\
\hline \multicolumn{11}{|c|}{ Controls } \\
\hline $\begin{array}{l}7 \\
8\end{array}$ & $\begin{array}{l}\text { PS, mild } \\
\text { TOF repair } \\
\text { PS, mild }\end{array}$ & $\begin{array}{l}14.0 \\
19.0\end{array}$ & $\begin{array}{l}\cdots \\
\cdots\end{array}$ & $\begin{array}{l}84 \\
74\end{array}$ & $\begin{array}{l}115 \\
125\end{array}$ & $\begin{array}{l}76 \\
78\end{array}$ & $\begin{array}{r}-2 \\
0\end{array}$ & $\dot{178}$ & 168 & $\cdots$ \\
\hline $\begin{array}{r}9 \\
10 \\
11 \\
12 \\
13\end{array}$ & $\begin{array}{l}\text { PS, mild } \\
\text { PS, trivial } \\
\text { AS, mild } \\
\text { VSD repair } \\
\text { AS, trivial }\end{array}$ & $\begin{array}{r}20.2 \\
13.7 \\
13.6 \\
19.5 \\
3.1\end{array}$ & $\begin{array}{l}\ldots \\
\cdots \\
\cdots \\
\ldots\end{array}$ & $\begin{array}{l}90 \\
75 \\
82 \\
78 \\
95\end{array}$ & $\begin{array}{l}136 \\
112 \\
108 \\
122 \\
110\end{array}$ & $\begin{array}{l}75 \\
60 \\
78 \\
76 \\
73\end{array}$ & $\begin{array}{r}-2 \\
-5 \\
0 \\
-2 \\
1\end{array}$ & $\begin{array}{l}200 \\
188 \\
180 \\
170\end{array}$ & $\begin{array}{l}134 \\
140 \\
140 \\
141\end{array}$ & $\begin{array}{l}\cdots \\
\cdots \\
\cdots \\
\cdots\end{array}$ \\
\hline $\begin{array}{l}\text { Mean } \\
\pm S D\end{array}$ & & $\begin{array}{r}15.4 \\
\pm 4\end{array}$ & $\begin{array}{l}\ldots \\
\ldots\end{array}$ & $\begin{array}{r}83 \\
\pm 8\end{array}$ & $\begin{array}{r}118 \\
\pm 10\end{array}$ & $\begin{array}{r}74 \\
\pm 6\end{array}$ & $\begin{array}{l}-1.4 \\
\pm 2.0\end{array}$ & $\begin{array}{r}183 \\
\pm 11\end{array}$ & $\begin{array}{r}147 \\
\pm 12\end{array}$ & $\ldots$ \\
\hline
\end{tabular}

* Coarctation repair group versus control group.

$A S=$ aortic stenosis; $A s A O=$ ascending aorta; $C$ of $A=$ coarctation of aorta; DescAo = descending aorta; dias = diastolic; $H R=$ heart rate; $\mathrm{NS}=$ not significant at $\mathrm{p}<0.05 ; \mathrm{PS}=$ pulmonic stenosis; Rt = right; $\mathrm{SD}=$ standard deviation; syst $=$ systolic; TOF = tetralogy of Fallot; $\mathrm{VSD}=$ ventricular septal defect.

results, and another (Patient 6) had trivial mitral insufficiency. No patient had aortic insufficiency or aberrant right subclavian artery.

Outpatient blood pressure was measured by auscultation in the right arm and by the use of a Doppler flow probe over the posterior tibial artery. Blood pressure cuffs of appropriate size, covering at least two thirds of the limb, were used on the right upper arm and calf. All reported blood pressure values are the average of at least 3 measurements.

Dynamic exercise testing was performed on a motorized treadmill according to the Bruce protocol. ${ }^{12}$ All children exercised to physical exhaustion defined as inability to exercise further despite vigorous encouragement from the staff to do so. Leads II, aVF, and $V_{5}$ were recorded throughout the exercise study. Blood pressure was measured by auscultation in the right arm and by the use of a Doppler flow probe over the posterior tibial artery. Blood pressure cuffs of appropriate size, covering at least two thirds of the limb, were used on the right upper arm and calf. Simultaneous supine arm and leg blood pressure measurements were made at rest (reported values are the average of at least 3 measurements) and within 30 seconds after the conclusion of exercise.

After obtaining informed consent, all patients underwent cardiac catheterization to evaluate their coarctation repair site and to determine a possible explanation for their resting and exercise hypertension.

During diagnostic cardiac catheterization, resting baroreceptor function was evaluated in each patient before angiography. All patients received light sedation with morphine sulfate $(0.1 \mathrm{mg} / \mathrm{kg}$, maximum $5 \mathrm{mg})$ and diphenhydramine (1 $\mathrm{mg} / \mathrm{kg}$, maximum $50 \mathrm{mg}$ ). The $\mathrm{R}-\mathrm{R}$ interval was measured directly from lead II of the electrocardiogram, recorded at a paper speed of $100 \mathrm{~mm} / \mathrm{s}$. Arterial pressure was recorded from a catheter situated in the aortic arch proximal to the site of $\mathrm{C}$ of $\mathrm{A}$ repair. Mean arterial pressure (MAP) was determined by electronic damping and was recorded, together with phasic arterial pressure, continuously throughout the study. Incremental changes in MAP were produced by injection (over 10 to 15 seconds) into the inferior vena cava of small doses of phenylephrine (50 to $150 \mu \mathrm{g}$ ) and nitroprusside (25 to $50 \mu \mathrm{g})$. Each drug was diluted in $0.9 \%$ sodium chloride and the total volume of each injection never exceeded $4 \mathrm{ml}$. In each subject, 3 or 4 doses each of phenylephrine and nitroprusside were administered to produce small (10\%) to moderate (25\%) increases and decreases in MAP. Three- to 5-minute intervals were taken between each drug injection to allow MAP and $\mathrm{R}$-R interval to return to baseline levels. After each drug injection, MAP and R-R interval increased or decreased within 


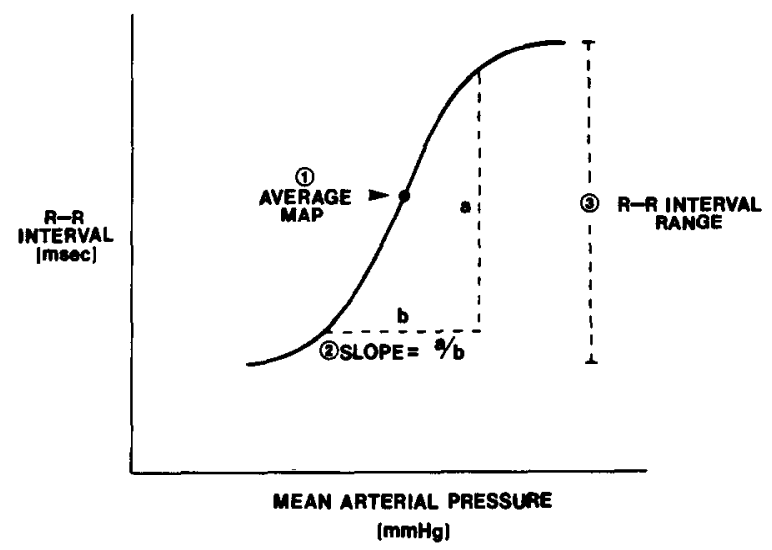

FICURE 1. Idealized baroreceptor function curve. The curve is characterized by 3 parameters: (1) average baseline mean arterial pressure (MAP); (2) slope (a/b); and (3) R-R interval range.

15 seconds to a new plateau level which was sustained for 10 to 20 seconds. MAP was measured at baseline before, and at the plateau after each injection. The $R-R$ interval was also measured at each baseline and plateau and the values reported represent the average of 3 consecutive $R-R$ interval measurements. The range of MAP over which baroreceptor function was studied was comparable in the $\mathrm{C}$ of $\mathrm{A}$ repair and control group averages of $42.2 \pm 2.7 \mathrm{~mm} \mathrm{Hg}$ and $44.1 \pm 2.9 \mathrm{~mm}$ $\mathrm{Hg}$, respectively $(\mathrm{p}=0.61)$.

Steady-state baroreceptor function curves were then constructed for each child by relating each R-R interval to its corresponding MAP value. Sigmoidal curves were constructed using the cumulative standard normal distribution function $(\phi)^{*}$. This sigmoidal function was utilized since previous studies have shown that the baroreceptor function curve is sigmoidal in nature. ${ }^{11}$ Each patient's baroreceptor function curve was defined by the following equation: $R R=A+B$ $\phi(\mathrm{MAP}-\overline{\mathrm{MAP}}) / \mathrm{SD}_{\mathrm{i}}$, where $\mathrm{i}$ represents phenylephrine or nitroprusside, $R R$ represents each $R-R$ interval, and MAP each corresponding MAP value. $\overline{\mathrm{MAP}}$ is the average baseline MAP for the patient. SD represents the standard deviation for each patient of the MAP values measured after drug injections either with phenylephrine or nitroprusside. Since the relationship between $R-R$ interval and mean arterial pressure has been shown to be characterized by an asymmetric sigmoid curve, ${ }^{11} 2$ different standard deviations were used in constructing the upper and lower portions of the curve, respectively -one for the MAP values greater than MAP (that is, after phenylephrine) and another for the $\overline{\mathrm{MAP}}$ values less than MAP (such as after nitroprusside). This procedure permitted each curve to be asymmetrical if warranted by the data. A separate A and B were determined for each subject using least-squares linear regression, since data within subjects were correlated.

Each patient's baroreceptor function curve was characterized by 3 parameters: (1) average baseline MAP, (2) slope, and (3) R-R interval range. Figure 1 depicts an idealized baroreceptor curve with these 3 parameters indicated. Average baseline MAP ( $\overline{\mathrm{MAP}}$ ) is the average of all MAP values at baseline before each drug injection, and represents the setpoint pressure about which the baroreflex operates. The slope of a baroreceptor function curve is an index of baroreflex

$$
{ }^{*} \phi(y)=\int_{-\infty}^{y} \frac{1}{\sqrt{2 \pi}} e^{-x^{2} / 2} d x, \text { where } y=(\text { MAP }-\overline{\text { MAP }}) / S D
$$

sensitivity to changes in arterial pressure. In this study the reported slope is the average slope of the linear portion of the curve over a pressure range defined as $\overline{\mathrm{MAP}} \pm 1 \mathrm{SD}$ (standard deviation for each patient of all the MAP values measured after drug injections). For example, in Figure 1 the slope is $a / b$, where $b$ represents $\overline{\mathrm{MAP}} \pm 1 \mathrm{SD}$. The $\mathrm{R}-\mathrm{R}$ interval range is the difference between the $R-R$ interval at the upper and lower plateaus of the baroreceptor function curves. This represents the $R-R$ range over which the baroreflex operates.

Descending aortic angiograms were obtained on all $6 \mathrm{C}$ of A patients. The descending thoracic aorta at the $C$ of $A$ repair site and at the level of the diaphragm were measured using calibrated grids. In the 7 control patients, the descending thoracic aorta was measured from either the levophase of a right ventricular angiogram or from a left ventricular angiogram.

Statistical significance was assessed using Student's $t$ test. Group values are reported as mean \pm standard deviation.

\section{Results}

Arm systolic pressure at rest averaged $143.8 \pm 2.9 \mathrm{~mm}$ $\mathrm{Hg}$ for the 6 children with repaired $\mathrm{C}$ of A (Table I). This ranks in the 90th percentile for systolic pressure according to the National Heart, Lung, and Blood Institute's blood pressure charts for children. ${ }^{13}$ Resting systolic pressure was significantly lower in the control group, averaging $118.3 \pm 9.9 \mathrm{~mm} \mathrm{Hg}(\mathrm{p}<0.05)$. Resting diastolic pressure was normal in both groups, averaging $74.5 \pm 9.4 \mathrm{~mm} \mathrm{Hg}$ and $73.7 \pm 6.2 \mathrm{~mm} \mathrm{Hg}$ in the $\mathrm{C}$ of $\mathrm{A}$ repair and control groups, respectively. The $\mathrm{C}$ of $\mathrm{A}$ pressure gradient at rest averaged $7.8 \pm 10.6 \mathrm{~mm} \mathrm{Hg}$ in the 6 children with repaired $C$ of $A$. There was no significant difference between study and control patients with regard to resting heart rate. All children with repaired $\mathrm{C}$ of $\mathrm{A}$ had an abnormal blood pressure elevation in response to treadmill exercise (Table I). Upper extremity systolic pressure, measured immediately after exercise, averaged $223.3 \pm 13.6 \mathrm{~mm} \mathrm{Hg}$ in the coarctation repair group, compared with $146.6 \pm 12.1 \mathrm{~mm} \mathrm{Hg}$ for the control group $(p<0.001)$. There was no overlap of postexercise systolic pressure between the 2 groups. The coarctation pressure gradient increased to $75.2 \pm$ $33.2 \mathrm{~mm} \mathrm{Hg}$ immediately after exercise. Arm diastolic pressure immediately after exercise was not significantly different in the coaretation repair and control groups, averaging $73.5 \pm 15.2 \mathrm{~mm} \mathrm{Hg}$ and $66.6 \pm 17.8$ $\mathrm{mm} \mathrm{Hg}$, respectively. Maximal heart rate attained at peak exercise was also similar in the 2 groups. At cardiac catheterization, all children appeared to have a good hemodynamic repair of $\mathrm{C}$ of $\mathrm{A}$, with peak systolic gradients from ascending to descending aorta ranging from 0 to $20 \mathrm{~mm} \mathrm{Hg}$ (mean $8.5 \pm 7.3 \mathrm{~mm} \mathrm{Hg}$ ) (Table II). In all 6 patients, aortograms demonstrated a mild indentation of the descending aorta at the site of coarctation repair. However, in no patient was this residual narrowing $<70 \%$ of the size of the descending aorta at the level of the diaphragm (Table II).

Baroreceptor function, as defined by the steady-state relationship between mean arterial pressure and $R-R$ interval, was significantly different in the children with repaired $\mathrm{C}$ of $\mathrm{A}$ compared with control children. Figure 2 illustrates representative baroreceptor function curves of a child with repaired $\mathrm{C}$ of $\mathrm{A}$ and a control child. The 
TABLE II Pertinent Cardlac Catheterization in 6 Children With Repaired C of A and 7 Control Children

\begin{tabular}{|c|c|c|c|c|c|c|c|c|c|}
\hline \multirow[b]{2}{*}{ Patient } & \multirow{2}{*}{$\begin{array}{c}\text { HR } \\
\text { (beats/min) }\end{array}$} & \multicolumn{3}{|c|}{ AsAo Pressure $(\mathrm{mm} \mathrm{Hg})$} & \multicolumn{3}{|c|}{ DescAo Pressure (mm Hg) } & \multirow{2}{*}{$\begin{array}{l}\text { Size of Residual } \\
\text { Narrowing } \\
\text { (mm) }\end{array}$} & \multirow{2}{*}{$\begin{array}{c}\text { Size } \\
\text { Descending Ao } \\
\text { at Diaphragm } \\
(\mathrm{mm})\end{array}$} \\
\hline & & Syst & Dias & Mean & Syst & Dias & Mean & & \\
\hline \multicolumn{10}{|c|}{ Coarctation Repair } \\
\hline \multirow[t]{2}{*}{$\begin{array}{l}1 \\
2 \\
3 \\
4 \\
5 \\
6\end{array}$} & $\begin{array}{l}96 \\
84 \\
76 \\
80 \\
78 \\
72\end{array}$ & $\begin{array}{l}153 \\
128 \\
148 \\
145 \\
138 \\
142\end{array}$ & $\begin{array}{r}101 \\
83 \\
82 \\
80 \\
78 \\
78\end{array}$ & $\begin{array}{r}117 \\
97 \\
100 \\
100 \\
97 \\
100\end{array}$ & $\begin{array}{l}150 \\
123 \\
138 \\
145 \\
118 \\
129\end{array}$ & $\begin{array}{r}100 \\
80 \\
80 \\
80 \\
76 \\
76\end{array}$ & $\begin{array}{r}117 \\
97 \\
99 \\
100 \\
89 \\
96\end{array}$ & $\begin{array}{l}14.4 \\
15.3 \\
11.8 \\
16.6 \\
10.0 \\
12.5\end{array}$ & $\begin{array}{l}15.7 \\
19.4 \\
15.9 \\
21.4 \\
14.0 \\
17.8\end{array}$ \\
\hline & $\begin{array}{l}81 \\
\pm 8.4 \\
\text { NS }\end{array}$ & $\begin{array}{l}141.1 \\
\pm 9.3 \\
<0.05\end{array}$ & $\begin{array}{l}83.6 \\
\pm 8.7 \\
\text { NS }\end{array}$ & $\begin{array}{l}101 \\
\pm 7.5 \\
p<0.01\end{array}$ & $\begin{array}{c}132.6 \\
\pm 14 \\
\text { NS }\end{array}$ & $\begin{array}{r}82 \\
\pm 9 \\
\text { NS }\end{array}$ & $\begin{array}{l}99.6 \\
\pm 9.3 \\
\text { NS }\end{array}$ & $\begin{array}{r}13.4 \\
\pm 2.4 \\
\ldots\end{array}$ & $\begin{array}{c}17.4 \\
\pm 2.7 \\
\text { NS }\end{array}$ \\
\hline \multicolumn{10}{|c|}{ Contral } \\
\hline \multirow[t]{2}{*}{$\begin{array}{r}7 \\
8 \\
9 \\
10 \\
11 \\
12 \\
13\end{array}$} & $\begin{array}{l}84 \\
72 \\
93 \\
89 \\
82 \\
69 \\
88\end{array}$ & $\begin{array}{r}112 \\
110 \\
125 \\
112 \\
118 \\
98 \\
123\end{array}$ & $\begin{array}{l}70 \\
71 \\
78 \\
72 \\
74 \\
62 \\
88\end{array}$ & $\begin{array}{l}83 \\
82 \\
93 \\
85 \\
88 \\
84 \\
99\end{array}$ & $\begin{array}{l}120 \\
108 \\
130 \\
118 \\
120 \\
100 \\
123\end{array}$ & $\begin{array}{l}70 \\
71 \\
77 \\
72 \\
73 \\
62 \\
88\end{array}$ & $\begin{array}{l}82 \\
81 \\
94 \\
85 \\
88 \\
84 \\
99\end{array}$ & $\begin{array}{l}\ldots \\
\cdots \\
\cdots \\
\cdots \\
\cdots \\
\ldots\end{array}$ & $\begin{array}{l}13.7 \\
17.3 \\
19.6 \\
16.7 \\
13.4 \\
17.4 \\
13.2\end{array}$ \\
\hline & $\begin{array}{r}82.4 \\
\pm 8.9 \\
\end{array}$ & $\begin{array}{l}114 \\
\pm 9.1 \\
\end{array}$ & $\begin{array}{r}73.5 \\
\pm 8.0 \\
\end{array}$ & $\begin{array}{r}87.7 \\
\pm 6.2 \\
\end{array}$ & $\begin{array}{l}117 \\
\pm 9.9 \\
\end{array}$ & $\begin{array}{r}73.3 \\
\pm 7.9 \\
\end{array}$ & $\begin{array}{r}87.5 \\
\pm 6.6 \\
\end{array}$ & $\begin{array}{l}\cdots \\
\cdots \\
\end{array}$ & $\begin{array}{r}15.9 \\
\pm 2.5 \\
\end{array}$ \\
\hline
\end{tabular}

Grad = gradient; other abbreviations as in Table I.

data describe sigmoidal curves with well-defined slopes in the mid-portion of the curves and clear upper and lower plateaus. Table III lists the baroreceptor function curve characteristics for the 2 groups of children. The average baseline mean arterial pressure (MAP) was $108.8 \pm 6.6 \mathrm{~mm} \mathrm{Hg}$ for the repaired $\mathrm{C}$ of A group compared with $90.4 \pm 8.6 \mathrm{~mm} \mathrm{Hg}$ for the control group (p $<0.01$ ). Thus, the baroreflex has been reset to operate at high arterial pressure levels in the children with repaired $\mathrm{C}$ of $\mathrm{A}$. The baroreceptor function curves of the children with repaired $\mathrm{C}$ of $\mathrm{A}$ have diminished slopes compared with control curves. In these children, the

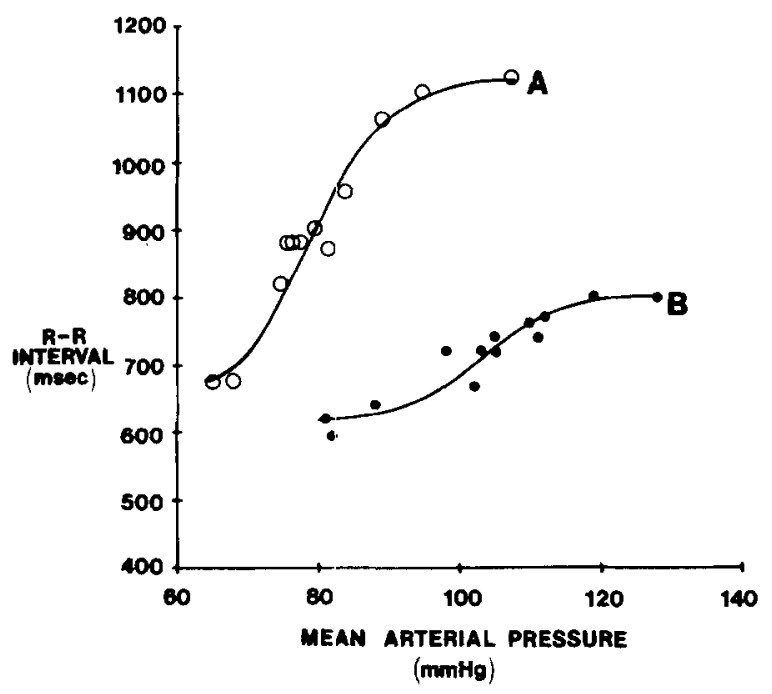

FIGURE 2. Representative individual baroreceptor function curves. $A$ $=$ curve of control, Patient 12. $\mathrm{B}=$ curve of coarctation repair, Patient 2 . slope averages $7.9 \pm 3.7 \mathrm{~ms} / \mathrm{mm} \mathrm{Hg}$, compared with 17.4 $\pm 5.1 \mathrm{~ms} / \mathrm{mm} \mathrm{Hg}$ in the control group ( $p<0.001)$, a $55 \%$ difference. This indicates diminished baroreflex sensitivity to changes in arterial pressure in the children with repaired $\mathrm{C}$ of $\mathrm{A}$. Finally, the R-R interval range averages $246.7 \pm 81.5 \mathrm{~ms}$ in the $\mathrm{C}$ of A repair group compared with $535.7 \pm 97.2 \mathrm{~ms}$ in the control group ( $\mathrm{p}$ $<0.001)$. Figure 3 illustrates the composite baroreceptor

TABLE III Baroreceptor Function Curve Characteristics In Children With Repaired Coarctation and In Control Children

\begin{tabular}{|c|c|c|c|}
\hline Patient & MAP (mm Hg) & $\begin{array}{c}\text { Slope } \\
\text { (ms } / \mathrm{mm} \mathrm{Hg})\end{array}$ & $\begin{array}{l}\text { R-R Interval } \\
\text { Range (ms) }\end{array}$ \\
\hline \multicolumn{4}{|c|}{ Coarctation Repair } \\
\hline $\begin{array}{l}1 \\
2 \\
3 \\
4 \\
5 \\
6\end{array}$ & $\begin{array}{l}121 \\
104 \\
110 \\
110 \\
104 \\
104\end{array}$ & $\begin{array}{r}5.2 \\
7.0 \\
6.5 \\
8.7 \\
5.1 \\
14.8\end{array}$ & $\begin{array}{l}230 \\
240 \\
170 \\
320 \\
160 \\
360\end{array}$ \\
\hline $\begin{array}{l}\text { Mean } \\
\pm S D \\
\text { p value }\end{array}$ & $\begin{array}{c}109 \\
7 \\
<0.01 \\
\end{array}$ & $\begin{array}{l}7.9 \\
\pm 3.7 \\
<0.001 \\
\end{array}$ & $\begin{array}{c}246.7 \\
\pm 81.5 \\
<0.001 \\
\end{array}$ \\
\hline \multicolumn{4}{|c|}{ Controls } \\
\hline $\begin{array}{r}7 \\
8 \\
9 \\
10 \\
11 \\
12 \\
13\end{array}$ & $\begin{array}{l}90 \\
86 \\
95 \\
88 \\
96 \\
80 \\
98\end{array}$ & $\begin{array}{l}17.4 \\
10.1 \\
20.9 \\
17.0 \\
19.7 \\
16.4 \\
20.3\end{array}$ & $\begin{array}{l}590 \\
390 \\
550 \\
700 \\
530 \\
450 \\
540\end{array}$ \\
\hline $\begin{array}{l}\text { Mean } \\
\pm S D\end{array}$ & $\begin{array}{r}90 \\
9 \\
\end{array}$ & $\begin{array}{r}17.4 \\
3.6 \\
\end{array}$ & $\begin{array}{r}536 \\
97 \\
\end{array}$ \\
\hline
\end{tabular}

* Compared with control values.

MAP = average baseline mean arterial pressure; other abbreviations as in Table 1 . 


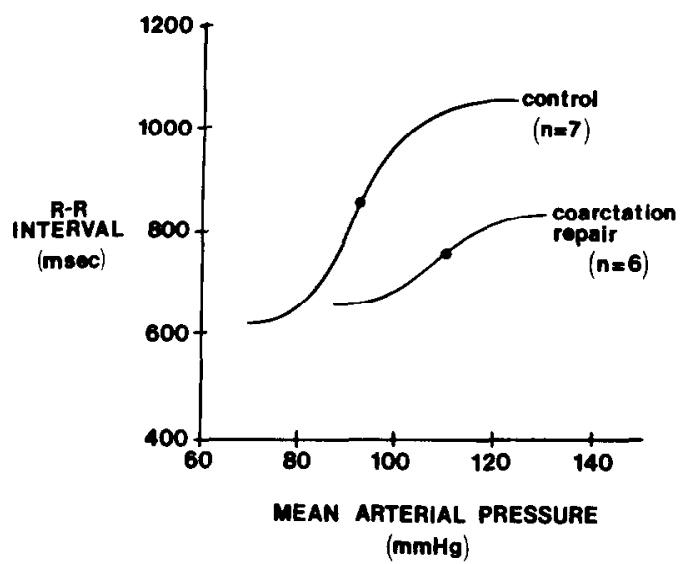

FIGURE 3. Composite baroreceptor curves of children with repaired coarctation and control children. The curves clearly differ in regard to average baseline MAP, slope, and R-R interval range.

function curves of the 6 children with repaired $\mathrm{C}$ of $\mathrm{A}$ and the 7 control children. These curves were constructed with the standard formula using averaged $\overline{\mathrm{MAP}}, \mathrm{A}, \mathrm{B}$, and SD (square root of averaged individual variances) values for the 2 groups. The two composite baroreceptor curves are clearly different. The $\mathrm{C}$ of $\mathrm{A}$ repair curve has been reset to a higher average baseline MAP and has a diminished slope compared with the control curve. The decrease in $R-R$ interval range of the $\mathrm{C}$ of $\mathrm{A}$ repair curve is shown to be due to a lowering of the upper R-R interval plateau, indicating a diminished bradycardiac response to arterial pressure elevation.

Baseline arterial pulse pressure was higher in the children with repaired $\mathrm{C}$ of $\mathrm{A}$ than in the control children, averaging $58.6 \pm 8.4 \mathrm{~mm} \mathrm{Hg}$ and $40.4 \pm 4.2 \mathrm{~mm}$ $\mathrm{Hg}$, respectively $(\mathrm{p}<0.05)$. After injection of phenylephrine or nitroprusside, however, the changes in pulse pressure were not significantly different bctween groups. The baroreceptor characteristics discussed above are not corrected for baseline pulse pressure differences. An adjustment for differences in pulse pressure would further increase the discrepancy in baroreceptor function between the 2 groups, since baroreflex sensitivity is known to be enhanced by increased pulse pressure. ${ }^{14}$

\section{Discussion}

The present study has documented altered baroreceptor function in a group of children with repaired $\mathrm{C}$ of A who have mild arm systolic hypertension. In these children the baroreflex is reset to operate at higher arterial pressure levels and has a reduced sensitivity to changes in arterial pressure compared with control children. The diminished baroreceptor sensitivity (slope) was marked, averaging only $45 \%$ of the control value. In addition, the baroreceptor curve of the $C$ of $A$ repair group had a reduced $R-R$ interval plateau, due almost entirely to a decrease in the upper R-R interval plateau. The level of the upper R-R interval plateau is dependent upon the degree of vagal efferent excitation and cardiac sympathetic inhibition, while the lower R-R interval plateau is determined by the degree of sympathetic excitation and vagal inhibition. We do not know which cardiac effector mechanism is altered in the children with repaired $\mathrm{C}$ of $\mathrm{A}$ but, based on studies of hypertensive adults, ${ }^{11}$ the reduced upper $R-R$ interval plateau seems more likely due to impaired vagal excitation than to impaired sympathetic inhibition.

The findings of the present study are similar to those of previous studies reporting altered baroreceptor function in adults with chronic essential hypertension. ${ }^{9-11}$ Korner et al, ${ }^{11}$ using a technique similar to ours to characterize steady-state baroreceptor function, also showed resetting, reduced baroreflex sensitivity, and a diminished R-R interval range in adults with chronic hypertension. In Korner's study the baroreceptor curve slopes of adults older than 30 years with severe resting hypertension (average MAP $151 \mathrm{~mm} \mathrm{Hg}$ ) averaged 11 $\mathrm{ms} / \mathrm{mm} \mathrm{Hg}$ compared with $21 \mathrm{~ms} / \mathrm{mm} \mathrm{Hg}$ for agematched control subjects. These findings are quantitatively very similar to those of the present study. It is, however, important to note that although the technique of measuring heart rate response to injections of pressor and depressor drugs free of cardiac action is the most widely used test of baroreflex function in human subjects, it has the limitation of being unable to directly measure the baroreflex control of the peripheral circulation. Despite this, with the exception of denervation of either the carotid sinus or aortic arch baroreceptors, ${ }^{14}$ most studies in both $\operatorname{man}^{15}$ and animals ${ }^{14,16,17}$ have demonstrated that with intact afferents there is a positive correlation between the heart rate and the arterial pressure responses to a baroreceptor manipulation. Thus, although we have only documented an abnormal heart rate response to baroreceptor stimulation in our children after $\mathrm{C}$ of A repair, we feel that it is likely that an abnormality of baroreceptor regulation of vascular resistance is also present.

Baroreceptor function has not previously been evaluated in children or adults with $\mathrm{C}$ of $\mathrm{A}$. Two previous studies have, however, demonstrated altered baroreceptor function in dogs with experimental coarctation. Bonchek et $\mathrm{al}^{7}$ reported resetting of the baroreflex to a higher pressure level, but normal reflex sensitivity, in 10 Labrador puppies with surgically created C of A. More recently, Igler et $\mathrm{al}^{8}$ described both resetting and diminished baroreflex sensitivity in dogs with $\mathrm{C}$ of $\mathrm{A}$ studied under nonpulsatile flow conditions. Baroreceptor function was found to be normal after surgical repair of the experimental $\mathrm{C}$ of $\mathrm{A}$.

The cause of altered baroreceptor function in hypertension has not been clearly elucidated. Although either the afferent or efferent limb of the reflex may be involved, most investigators have suspected that the changes reside in the afferent limb. Support for this view is found in animal studies, using single or multifiber preparations from the aortic and carotid sinus nerves, which have demonstrated an elevated threshold pressure (the pressure at which distinct nerve discharge first begins), an elevated saturation pressure (the pressure at which nerve firing no longer increases with increased pressure), and a decreased sensitivity (slope 
of the stimulus-response curve over its linear range). ${ }^{8,18,19}$ Such diminished baroreceptor responsiveness to elevated arterial pressure may involve 1 or more mechanisms. First, diminished baroreceptor function in hypertension may involve dysfunction of the afferent neuronal baroreceptor fibers themselves. Generalized destruction or inactivation of these receptor fibers could, in theory, depress baroreflex sensitivity. Angell-James ${ }^{19}$ has presented histologic evidence of baroreceptor degeneration in the aortic arch of hypertensive rabbits. Similar findings in hypertensive persons have also been reported. ${ }^{20}$ Second (and a more likely mechanism), with chronic hypertension, medial hypertrophy, elastic fiber degeneration, atherosclerosis, and changes in vessel sodium and water content may develop. These changes in the arterial wall may all act to diminish arterial wall compliance and thereby depress the baroreflex. ${ }^{21}$ In addition to the effects of chronic hypertension, morphologic arterial wall abnormalities may occur in patients with coarctation which may further decrease vessel compliance. ${ }^{22-24}$ Specifically, Sehested et al $^{24}$ have demonstrated, both by in vitro stimulation of aortic tissue from patients with $\mathrm{C}$ of $\mathrm{A}$ and by morphologic analysis, that the precoarctation aortic wall is more rigid and contains significantly more collagen and less smooth muscle than the postcoarctational wall. They speculated ${ }^{24}$ that this reduced distensibility may influence baroreceptors in the upper vascular bed in such a way as to tolerate a higher pressure.

The findings of the present study suggest but do not prove that there may be a relationship between the observed abnormality in baroreceptor function and the presence of both resting and exercise hypertension in children with repaired C of A. There is no unanimity in the literature with regard to either the relationship between diminished baroreflex gain and hyperten$\operatorname{sion}^{25,26}$ or the ability of the baroreflexes to modify the cardiovascular response to exercise. ${ }^{27-30}$ Floras et al ${ }^{27}$ demonstrated that adults with abnormal baroreflexes respond to a standard exercise test with a greater increase in blood pressure than that observed in adults with normal baroreflexes. Although altered baroreceptor function may contribute to both the maintenance of resting hypertension and the development of exercise hypertension after successful repair of $\mathrm{C}$ of $\mathrm{A}$, we feel that it is not the major cause of the hypertension. Probably more important other causes include the magnitude $^{24}$ and duration ${ }^{1}$ of preoperative hypertension, the mild residual narrowing of the descending thoracic aorta that is usually present after $\mathrm{C}$ of $\mathrm{A}$ repair,,$^{5}$ and the possible decreased distensibility of the ascending aortic wall. ${ }^{24}$ Studies of the baroreceptor function in children with repaired $C$ of $A$ who have normal resting and exercise blood pressure would help to clarify these relationships.
Acknowledgment: We thank Paula Therrien and Fran Moore for their excellent secretarial work, Richard Creyts for his technical assistance, and Michael A. Schork, $\mathrm{PhD}$, for his valuable statistical assistance.

\section{References}

1. Maron BJ, Humphries JO, Rowe RD, Mellits ED. Prognosis of surgically corrected coarctation of the aorta. A 20 year postoperative appraisal. Circulation 1973;47:119-126.

2. Simon $A B$, Zlolo $A E$. Coarctation of the aorta. Longitudinal assessment of operated patients. Circulation 1974;50:456-563.

3. James $\mathbf{F W}$, Kaplan $\mathbf{S}$. Systolic hypertension during submaximal exercise after correction of coarctation of the aorta. Circulation 1974;50:11271134.

4. Connor TM. Evaluation of persistent coarctation of the aorta after surgery with blood pressure measurement and exercise testing. Am J Cardiol 1969;43:74-78

5. Freed MD, Rocchini A, Rosenthal A, Nadas AS, Castaneda AR. Exercise-induced hypertension after surgical repair of coarctation of the aorta. Am J Cardiol 1979;43:253-258.

6. Beekman RH, Rocchini AP, Behrendt DM, Rosenthal A. Reoperation for coarctation of the aorta. Am J Cardiol 1981;48:1108-1114.

7. Bonchek LI, Doctor A, Rees PM. Baroreflex sensitivity and carotid sinus dimensions in dogs with coarctation. J Appl Physiol 1976;41:36-40.

8. Igler FO, Boerboom LE, Werner PH, Donegan JH, Zuperku EJ, Bonchek Li. Kampine JP. Coarctation of the aorta and baroreceptor resetting. A study of carotid baroreceptor stimulus-response characteristics before and after surgical repair in the dog. Circ Res 1981;48:365-371.

9. Bristow JD, Honous AJ, Pickering GW, Sieight P, Smyth HS. Diminished baroreflex sensitivity in high blood pressure. Circulation 1969;39:48-54.

10. Gribbin B, Pickering TG, Sleight P, Peto R. Effect of age and high blood pressure on baroreflex sensitivity in man. Circ Res 1971;29:424-432.

11. Korner PI, West MJ, Uther JB. "Steady-state" properties of the baroreceptor-heart rate reflex in essential hypertension in man. Clin Exp Pharm Physiol 1974:1:65-76.

12. Doen AE, Peterson DR, Blackmon JR, Bruce RA. Myocardial ischemia after maximal exercise in healthy men. Am Heart J 1965;69:11-18.

13. National Heart, Lung, and Blood Institute's Task Force on Blood Pressure Control in Children. Report of the task force on blood pressure control in children. Pediatrics 1977:59:797-799.

14. Guo GB, Thames MD, Abboud FM. Differential baroreflex control of heart rate and vascular resistance in rabbits. Circ Res 1982;50:554-565.

15. Mancla G, Ferradi A, Gregorini L, Valentini R, Ludbrook J, Fauchette A. Circulatory reflexes from carotid and extracarotid baroreceptor areas in man. Circ Res 1977;41:309-315.

16. Scher AM, Young AC. Reflex control of heart rate in the unanesthetized dog. Am J Physiol 1970;218:780-789.

17. Eckberg D. Carotid baroreflex function in young men with borderline blood pressure elevation. Circulation 1979;59:632-636.

18. McCubbin JW, Green JH, Page IH. Baroreceptor function in chronic renal hypertension. Circ Res 1956;4:205-212.

19. Angell-James JE. Characteristics of single aortic and right subclavian baroreceptor fiber activity in rabbits with chronic renal hypertension. Circ Res 1973;32:149-162.

20. Hilgenberg F. Neurohistologic studies of the carotid sinus baroreceptors in hypertension. In: Kezdi $P$, ed. Baroreceptors and Hypertension. Oxford: Pergamon Press, 1967:293-330.

21. Kirchhelm HR. Systemic arterial baroreceptor reflexes. Physiol Rev 1976:56:100-176.

22. Connor TM, Baker WP. A comparison of coarctation resection and patch angioplasty using postexercise blood pressure measurements. Circulation 1981;64:567-574.

23. Edwards JE. Congenital malformations of the heart and great vesseis. In Gould S, ed. Pathology of the Heart and Blood Vessels. 3rd ed. Springfield IL: Charles C Thomas, 1968:422-428.

24. Sehested J, Baandrup U, Mlkkelsen E. Different reactivity and structure of the prestenotic and poststenotic aorta in human coarctation. Circulation 1982;65:1060-1065.

25. Cowley AW, Llard JF, Guylon AC. Role of the baroreceptor reflex in daily control of arterial pressure and other variables in dogs. Girc Res 1973 32:564-576.

26. Sleight P. Reflex control of the heart. Am J Cardiol 1979;44:889-894

27. Floras JS, Hassen MO, Jones JV, Sever PS, Slelght P, Turner K. Baroreflex sensitivity and plasma noradrenaline concentration in relation to the blood pressure during dynamic exercise in hypertension (abstr). I Physiol (Lond) 1979;291:44P

28. McRltchle RJ, Valner SF, Boeticher D, Heyndricks GR, Patrick TA, Braunwald E. Role of arterial baroreceptors in mediating cardiovascular response to exercise. Am J Physiol 1976;230:85-94.

29. Krasney JA, Levitzky MG, Koehler RD. Sinoaortic contribution to the adjustment of systemic resistance in exercise dogs. J Appl Physiol 1974; 36:679-685

30. Bevegard BS, Shepherd JT. Circulatory effects of stimulating the carotid arterial stretch receptors in man at rest and during exercise. J Clin Invest 1966;45:132-141. 